\title{
Binary and Ternary 3D nanobundles Transition Metal Oxides Functionalized Carbon Xerogels as Electrocatalysts toward Oxygen Reduction Reaction
}

\author{
Abdalla Abdelwahab ${ }^{1, *}$, Francisco Carrasco-Marín ${ }^{2,3}$ and Agustín F. Pérez-Cadenas ${ }^{2,3}$ \\ ${ }^{\mathbf{1}}$ Materials Science and Nanotechnology Department, Faculty of Postgraduate Studies for Advanced Sciences, Beni-Suef \\ University, Beni-Suef 62511, Egypt. \\ ${ }^{2}$ Carbon Materials Research Group, Department of Inorganic Chemistry, Faculty of Sciences, University of Granada. Campus \\ Fuentenueva s/n, Granada 18071, Spain. \\ ${ }^{3}$ Unit of Excellence in Chemistry applied to Biomedicine and the Environment of the University of Granada, Spain. \\ *Correspondence: Tel: +2-082 2244135, E-mail: aabdelwahab@psas.bsu.edu.eg
}




\begin{abstract}
A series of carbon xerogels doped with cobalt, nickel and iron have been prepared through the sol-gel method. The doped carbon xerogels were further functionalized with binary and ternary transition metal oxides; namely nickel cobaltite, zinc cobaltite and zinc-nickel-cobalt oxide by hydrothermal method. A development in the mesopore volume is achieved for functionalized carbon xerogel doped with iron. However, in functionalization of carbon xerogel with ternary metal oxides a reduction in pore diameter and mesopore volume is found. In addition, all functionalized metal oxides/carbon are in the form of 3D nanobundles with different lengths and widths. The prepared samples have been tested as electro-catalysts for oxygen reduction reaction (ORR) in basic medium. The activity of functionalized cobalt doped carbon xerogel toward ORR is higher than that for functionalized carbon doped with iron or nickel. Among all the prepared samples being nickel cobaltite functionalized cobalt doped carbon xerogels $\left(\mathrm{NiCo}_{2} \mathrm{O}_{4} / \mathrm{Co}-\mathrm{CX}\right)$ the best active electro-catalyst for oxygen reduction reaction with lowest onset potential of -0.06 $\mathrm{V}$. The activity of $\mathrm{NiCo}_{2} \mathrm{O}_{4} / \mathrm{Co}-\mathrm{CX}$ is attributed to its lower equivalent series resistance of 2.37 $\Omega$ together with its higher affinity for ionic adsorption exhibited from electrochemical impedance spectroscopy study.
\end{abstract}

Keywords: Metal oxides; Carbon Xerogel; Equivalent series resistance; Oxygen reduction reaction. 


\section{Introduction}

The negative effects that fossil combustion has had upon the environment has created a demand to develop and implement alternative clean energy sources ${ }^{1-2}$. Fuel cells can dramatically decrease the greenhouse gas emissions because it is considered as zero carbon emissions device. Proton exchange membrane (PEM) fuel cell is the most widely used fuel cell in potential applications such as vehicles and power units ${ }^{3-4}$. Unfortunately, the high cost per unit energy delivered reduces the use of PEM fuel cell in a large scale and introducing to market. This problem can be solved either by reducing the used fuel cost, typically $\mathrm{H}_{2}$, or searching for electrocatalyst that enhance the overall efficiency and energy generation.

The fuel cell half reactions are anodic hydrogen oxidation reaction (HOR) and cathodic oxygen reduction reaction (ORR). The overpotential for HOR is considered as negligible while for ORR it requires high energy to initiate the reaction due to large kinetic inhibition. Thus, the oxygen reduction reaction (ORR) is considered as the rate determining step and reducing its overpotential will enhance the fuel cell efficiency. It was found that the ORR can be carried out through four electron transfer pathway or two electron transfer pathway (see below). The four electron transfer pathway is the favored one because it forms the hydroxyl species rather than peroxide ${ }^{5-6}$ that causes membrane degradation and electrode fouling. The ORR reactions in both acidic and basic medium can be summarized as follows ${ }^{3,7}$.

Acidic media

$$
\begin{aligned}
& \mathrm{O}_{2}+4 \mathrm{H}^{+}+4 \mathrm{e}^{-} \longrightarrow 2 \mathrm{H}_{2} \mathrm{O} \text { direct (4 electron pathway) } \\
& \mathrm{O}_{2}+2 \mathrm{H}^{+}+2 \mathrm{e}^{-} \longrightarrow \mathrm{H}_{2} \mathrm{O}_{2} \text { indirect (2 electron pathway) } \\
& \mathrm{H}_{2} \mathrm{O}_{2}+2 \mathrm{H}^{+}+2 \mathrm{e}^{-} \longrightarrow 2 \mathrm{H}_{2} \mathrm{O}
\end{aligned}
$$


Alkaline media

$$
\begin{aligned}
& \mathrm{O}_{2}+2 \mathrm{H}_{2} \mathrm{O}+4 \mathrm{e}^{-} \longrightarrow 4 \mathrm{OH}^{-} \text {direct (4 electron pathway) } \\
& \mathrm{O}_{2}+\mathrm{H}_{2} \mathrm{O}+2 \mathrm{e}^{-} \longrightarrow \mathrm{HO}_{2}^{-}+\mathrm{OH}^{-} \text {indirect (2 electron pathway) } \\
& \mathrm{HO}_{2}^{-}+\mathrm{H}_{2} \mathrm{O}+2 \mathrm{e}^{-} \longrightarrow 3 \mathrm{OH}^{-}
\end{aligned}
$$

The peroxide formation can be avoided by using an effective electrocatalyst that force the reaction towards the four electron pathway. Platinum $(\mathrm{Pt})$ and its alloys are considered as the best electocatalysts for ORR that makes the reaction carried out through 4 electron pathway with the formation of only water as the product ${ }^{8-10}$. However, the platinum high cost and scarcity reduces its global use on a large scale on PEM. Recently, transition metal oxides based electrocatalysts, whether it is mono-metal, binary-metal, or ternary-metal oxides, become promising candidates for Pt-based materials in ORR application due to their active sites, high electronic conductivity, low cost and environmental benignity ${ }^{11-12}$. But, the activity of transition metal oxides toward ORR still unsatisfactory due to some reasons such as less electronic conductivities than Pt ones 13. Improving conductivity of transition metal oxides can be achieved through doping with electron donor or by their encapsulation in carbon matrix ${ }^{14-15}$. Jie Wang et.al, synthesized an electrocatalyst of hollow structured carbon supported nickel cobaltite nanoparticles for oxygen reduction and evolution reactions ${ }^{16}$. In this work, vulcan $\mathrm{XC}-72$ was used as the carbon source and they found that the hollow structure of nickel cobaltite increases the number of active sites which in turn increases the contact between the electrolyte and the catalyst results in improving the ORR activity.

Recently, carbon gel ${ }^{17-19}$ which is a novel carbon nanomaterial, finds applications in wide research areas due to its tunable surface area and porosity depending on the synthesis conditions 20-22. Carbon gels in its of both forms, aerogel and xerogel, were used in different fields such as 
catalysis ${ }^{23}$, energy storage ${ }^{24}$, and catalyst support in PEM fuel cell ${ }^{25}$. M.M. El-Deeb et al. ${ }^{26}$, prepare nickel cobaltite decorated carbon xerogel composite $\left(\mathrm{NiCO}_{2} \mathrm{O}_{4} / \mathrm{CX}\right)$ for methanol electrooxidation. The data shows a good catalytic current density of $98 \mathrm{~mA} \cdot \mathrm{cm}^{-2}$ at $0.29 \mathrm{~V}$ with stability reaches $90.6 \%$ after 100 repetitive cycles.

Although a numerous publications study the role of binary metal oxides on ORR activity, only a few reports study the effect of ternary transition metal oxides for ORR application ${ }^{27}$. Herein, we report the synthesis of novel electrocatalysts binary and ternary transition metal oxides functionalized carbon xerogels.

In this work, a series of carbon xerogel doped with three metals ( $\mathrm{M}-\mathrm{CX}$ i.e $\mathrm{M}=\mathrm{Co}, \mathrm{Ni}$, and $\mathrm{Fe}$ ) were prepared, to investigate the role of carbon support in ORR application. The doped carbon xerogels were prepared through the sol-gel method from resorcinol and formaldehyde monomers. After that, the doped carbon xerogel were further functionalized with binary and ternary transition metal oxides, i.e, nickel cobaltite $\left(\mathrm{NiCo}_{2} \mathrm{O}_{4}\right)$, zinc cobaltite $\left(\mathrm{ZnCo}_{2} \mathrm{O}_{4}\right)$ and zinc nickel cobalt oxide ( $\mathrm{Zn}-\mathrm{Ni}$-Co oxide), by the hydrothermal process to evaluate the role of metal oxides. The prepared materials will be tested as electrocatalysts to oxygen reduction reaction in basic medium.

\section{Materials and methods}

\subsection{Materials}

All used chemicals are of analytical grade which are used without further purification. These chemicals include resorcinol, formaldehyde, cobalt acetate, nickel acetate, iron acetate, urea, ethylene glycol, N, N-dimethylformamide, nafion solution (5wt.\%), ethanol, isopropanol, and potassium hydroxide. 


\subsection{Preparation of metal doped carbon xerogels (M-CX)}

Metal doped carbon xerogels were prepared from resorcinol and formaldehyde monomers through the sol-gel method published elsewhere ${ }^{28}$. Briefly, resorcinol (R) and formaldehyde (F) were mixed together with a molar ratio of 1:2 in presence of water (W) as solvent and metal acetate salt as the dopant $(\mathrm{C})$. The molar ratio between $\mathrm{R} / \mathrm{W}$ is $1: 17$ and the amount of metal dopant $(\mathrm{M}=\mathrm{Co}, \mathrm{Ni}$ and $\mathrm{Fe})$ was calculated to be $1 \mathrm{wt} . \%$ of the carbon matrix. After gelation, the obtained organic gels were subjected to microwave drying process followed by carbonization in $\mathrm{N}_{2}$ atmosphere at $900{ }^{\circ} \mathrm{C}$ for two hours with a heating rate of $1{ }^{\circ} \mathrm{C} / \mathrm{min}$.

\subsection{Preparation of binary $\left(\mathrm{XY}_{2} \mathrm{O}_{4} / \mathrm{M}-\mathrm{CX}\right)$ and ternary $(\mathrm{X}-\mathrm{Y}-\mathrm{Z}$ Oxide/M-CX) transition metal oxides functionalized carbon xerogel composites.}

In this preparation, $80 \mathrm{mg}$ of the prepared $\mathrm{M}-\mathrm{CX}$ was dispersed in $40 \mathrm{ml} \mathrm{N}$, Ndimethylformamide (DMF). For $\mathrm{NiCo}_{2} \mathrm{O}_{4} / \mathrm{M}-\mathrm{CX}, 0.5 \mathrm{mmol}$ of $\mathrm{Ni}(\mathrm{Ac})_{2} .6 \mathrm{H}_{2} \mathrm{O}, 1 \mathrm{mmol}$ of $\mathrm{Co}(\mathrm{Ac})_{2} \cdot 4 \mathrm{H}_{2} \mathrm{O}$ and $6 \mathrm{mmol}$ of urea were dissolved in $30 \mathrm{ml}$ of $\mathrm{H}_{2} \mathrm{O}$ and ethylene glycol solution with a volumetric ratio of $2: 1$. The two solutions were mixed together and sonicated for 15 minutes, then transferred into $100 \mathrm{ml}$ Teflon lined stainless steel autoclave and the temperature was held at $180{ }^{\circ} \mathrm{C}$ for $12 \mathrm{hrs}$. After cooling down to room temperature, the powder was separated with centrifugation then washed several times with water and ethanol followed by drying at $60{ }^{\circ} \mathrm{C}$ for $12 \mathrm{hr}$. Finally, the sample was calcined in air at $360{ }^{\circ} \mathrm{C}$ for $3 \mathrm{hrs}$. Same procedure was followed for preparation of $\mathrm{ZnCo}_{2} \mathrm{O}_{4} / \mathrm{Co}-\mathrm{CX}$ except with changing nickel precursor with zinc one. In addition, in preparation of ternary transition metal oxide/ carbon xerogel (Zn-Ni-Co oxide/ Co-CX) $0.5 \mathrm{mmol}$ of zinc acetate, $0.5 \mathrm{mmol}$ of nickel acetate, $1 \mathrm{mmol}$ 
of cobalt acetate and $6 \mathrm{mmol}$ of urea were mixed together and the same preparation steps were followed.

\subsection{Characterization of the prepared materials}

The surface areas and porosity of the prepared samples were characterized by $\mathrm{N}_{2}$-gas adsorption at $-196{ }^{\circ} \mathrm{C}$ (Quadrasorb, Boynton Beach, Florida, USA). Samples morphology is evaluated with scanning electron microscopy (SEM), Zeiss SUPRA40VP. The samples particle size is determined by high resolution transmission electron microscopy (HRTEM), FEI Titan G2 60300 microscope (FEI, Eindhoven, Netherlands). While samples crystallinity is characterized Xray diffraction (XRD) BRUKER D8 ADVANCE diffractometer (BRUKER, Rivas-Vaciamadrid, Spain). X-ray photoelectron spectroscopy (XPS) measurements were carried out with a physical electronics ESCA 5701 (PHI, Chanhassen, MN, USA) operating at $12 \mathrm{KV}$ and $10 \mathrm{~mA}$ and equipped with a $\mathrm{MgK}$ X-ray source $(\mathrm{hv}=1253.6 \mathrm{eV})$.

\subsection{Electrode preparation}

The working electrode was prepared with dispersing $5 \mathrm{mg}$ of the prepared materials in $400 \mu \mathrm{L}$ isopropanol and $30 \mu \mathrm{L}$ nafion solution (5wt.\%), then sonicated for 10 minutes. $10 \mu \mathrm{L}$ of the prepared ink were deposited onto rotating disk electrode (RDE) surface with $3 \mathrm{~mm}$ glassy carbon tip and dried under infrared lamp. 


\subsection{Electrochemical measurements}

All electrochemical measurements are performed using biologic VMP multichannel potentiostat with standard three electrodes electrochemical cell in which $\mathrm{Ag} / \mathrm{AgCl}$ electrode was used as reference while Pt-wire was used as counter electrode. $0.1 \mathrm{M} \mathrm{KOH}$ was chosen to be the used electrolyte. Cyclic voltammetry (CV) were carried out in $\mathrm{N}_{2}$ and $\mathrm{O}_{2}$ saturated electrolyte in a potential window ranging from -0.8 to $0.4 \mathrm{~V}$ with two scan rates $50 \mathrm{mV} \cdot \mathrm{s}^{-1}$ and $5 \mathrm{mV} \cdot \mathrm{s}^{-1}$. While linear sweep voltammograms (LSV) were obtained in $\mathrm{O}_{2}$ saturated electrolyte with different rotation speeds (from 500 to $4000 \mathrm{rpm}$ ) at $5 \mathrm{mV} \cdot \mathrm{s}^{-1}$. Data obtained from LSV were fitted to Koutecky-Levich model in order to determine the number of transferred electrons and the electro-catalytic performance of each sample as follows ${ }^{29-30}$.

$\frac{1}{j}=\frac{1}{j_{k}}+\frac{1}{B \omega^{0.5}}$

$B=0.2 n F\left(D_{O_{2}}\right)^{2 / 3} v^{-1 / 6} C_{O_{3}}$

where $j$ the current density; $j_{k}$ is kinetic current density; $\omega$ is the rotation speed; $\mathrm{n}$ is the number of transferred electrons per $\mathrm{O}_{2}$ molecule; $\mathrm{F}$ is Faraday constant; $D_{O_{n}}$ is the oxygen diffusion coefficient $\left(1.9 \times 10^{-5} \mathrm{~cm}^{2} \cdot \mathrm{s}^{-1}\right) ; v$ viscosity $\left(0.01 \mathrm{~cm}^{2} \cdot \mathrm{s}^{-1}\right) ; c_{O_{2}}$ oxygen concentration $\left(1.2 \times 10^{-6}\right.$ $\left.\mathrm{mol} \cdot \mathrm{cm}^{-3}\right)$

Electrochemical impedance spectroscopy (EIS) was performed in two electrode system in order to evaluate the electrode resistance and the equivalent series resistance. The applied frequency was ranging from $100 \mathrm{KHz}$ to $1 \mathrm{mHz}$. 


\section{Results and discussion}

\subsection{Physicochemical Properties}

The porous texture of the samples was characterized with $\mathrm{N}_{2}$ gas adsorption. Before analysis the samples were degassed at $100{ }^{\circ} \mathrm{C}$ for $12 \mathrm{hr}$. BET equation was applied to the obtained isotherms to calculate their corresponding surface areas. The data obtained from $\mathrm{N}_{2}$ gas adsorption are compiled in Table 1. In evaluating the porous texture of functionalized carbon support, the highest specific surface areas $\left(\mathrm{S}_{\mathrm{BET}}=74 \mathrm{~m}^{2} \mathrm{~g}^{-1}\right)$, micropore volumes $\left(\mathrm{W}_{\mathrm{o}}=0.03 \mathrm{~cm}^{3} \cdot \mathrm{g}^{-1}\right)$ and pore diameter $\left(\mathrm{L}_{\mathrm{o}}=3.23 \mathrm{~nm}\right.$ ) was found for functionalized iron doped carbon xerogel $\left(\mathrm{NiCo}_{2} \mathrm{O}_{4} / \mathrm{Fe}-\mathrm{CX}\right)$ followed by cobalt then nickel. While the lowest surface area, mesopore volume $\left(\mathrm{V}_{\text {meso }}\right)$ and pore diameter was obtained for ternary transition metal oxide functionalized carbon xerogel ( $\mathrm{Zn}-\mathrm{Ni}-\mathrm{Co} / \mathrm{Co}-\mathrm{CX})$. These data are also confirmed by applying the DFT equation to the adsorption part of $\mathrm{N}_{2}$ isotherms, Table 1. The DFT surface areas ( $\left.\mathrm{S}_{\mathrm{DFT}}\right)$ are ranging from $79-201 \mathrm{~m}^{2} \mathrm{gg}^{-1}$.

Table 1. Textural characteristics of the samples.

\begin{tabular}{lcccccccc}
\hline Sample & $\begin{array}{c}\mathrm{S}_{\mathrm{BET}} \\
\mathrm{m}^{2} / \mathrm{g}\end{array}$ & $\begin{array}{c}\mathrm{W}_{0}\left(\mathrm{~N}_{2}\right) \\
\mathrm{cm}^{3} / \mathrm{g}\end{array}$ & $\begin{array}{c}\mathrm{L}_{0}\left(\mathrm{~N}_{2}\right) \\
\mathrm{nm}\end{array}$ & $\begin{array}{c}\mathrm{V}_{0.95}\left(\mathrm{~N}_{2}\right) \\
\mathrm{cm}^{3} / \mathrm{g}\end{array}$ & $\begin{array}{c}\mathrm{V}_{\text {meso }}\left(\mathrm{N}_{2}\right) \\
\mathrm{cm}^{3} / \mathrm{g}\end{array}$ & $\begin{array}{c}\mathrm{S}_{\text {DFT }} \\
\mathrm{m}^{2} / \mathrm{g}\end{array}$ & $\begin{array}{c}\mathrm{V}_{\text {DFT }} \\
\mathrm{cm}^{3} / \mathrm{g}\end{array}$ & $\begin{array}{c}\mathrm{L}_{0}(\mathrm{DFT}) \\
\mathrm{nm}\end{array}$ \\
\hline $\mathrm{NiCo}_{2} \mathrm{O}_{4} / \mathrm{Co}-\mathrm{CX}$ & 64 & 0.03 & 2.98 & 0.30 & 0.27 & 128 & 0.32 & 2.84 \\
$\mathrm{NiCo}_{2} \mathrm{O}_{4} / \mathrm{Ni}-\mathrm{CX}$ & 57 & 0.02 & 2.20 & 0.27 & 0.24 & 103 & 0.31 & 2.60 \\
$\mathrm{NiCo}_{2} \mathrm{O}_{4} / \mathrm{Fe}-\mathrm{CX}$ & 74 & 0.03 & 3.23 & 0.44 & 0.41 & 201 & 0.38 & 2.84 \\
$\mathrm{ZnCo}_{2} \mathrm{O}_{4} / \mathrm{Co}-\mathrm{CX}$ & 57 & 0.02 & 2.35 & 0.27 & 0.25 & 122 & 0.25 & 2.60 \\
$\mathrm{Zn}-\mathrm{Ni}-\mathrm{Co} / \mathrm{Co}-\mathrm{CX}$ & 44 & 0.02 & 1.73 & 0.21 & 0.19 & 79 & 0.18 & 2.60 \\
\hline
\end{tabular}

Nickel cobaltite $\left(\mathrm{NiCo}_{2} \mathrm{O}_{4} / \mathrm{Co}-\mathrm{CX}\right)$ and zinc cobaltite $\left(\mathrm{ZnCo}_{2} \mathrm{O}_{4} / \mathrm{Co}-\mathrm{CX}\right)$ functionalized carbon xerogel, have comparable surface areas and pore diameter. However, a reduction in the mesopore volume and surface area of carbon xerogel doped with ternary metal oxide was found; $\mathrm{Zn}-\mathrm{Ni}$-Co 
oxide/Co-CX. The pore size distribution obtained from the DFT study is represented in Fig. 1. In which a development in the mesopore volume for carbon xerogel doped with iron.

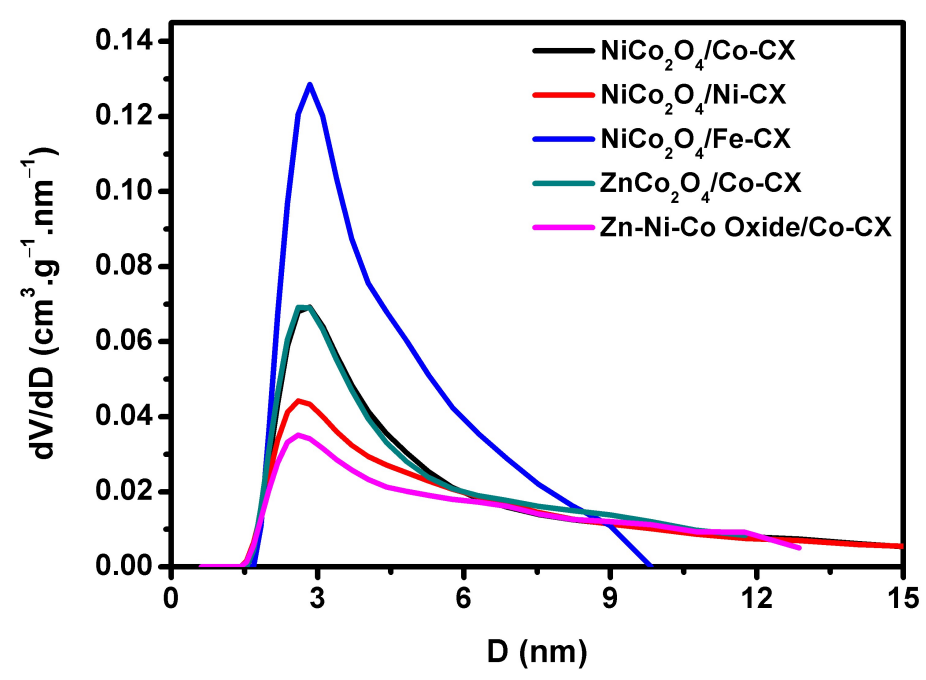

Figure 1: Pore size distribution from DFT analysis for the adsorption part of $\mathrm{N}_{2}$-isotherms.

Samples crystallinity were investigated with powder X-ray diffraction (XRD) and their corresponding pattern are given in Fig. 2. The XRD spectra for nickel cobaltite $\mathrm{NiCo}_{2} \mathrm{O}_{4}$ functionalized carbon xerogel are similar which indexed to the spinel structure of $\mathrm{NiCo}_{2} \mathrm{O}_{4}$ Fig. $2 \mathrm{a}^{31}$. There is an excess diffraction peak for $\mathrm{NiCo}_{2} \mathrm{O}_{4} / \mathrm{Co}-\mathrm{CX}$ at $2 \theta$ of $43^{\circ}$ which is corresponding to (200) plane. The XRD spectra for $\mathrm{ZnCo}_{2} \mathrm{O}_{4} / \mathrm{Co}-\mathrm{CX}$ and $\mathrm{Zn}-\mathrm{Ni}-\mathrm{Co}$ oxide/CoCX, Fig. $2 b$, are identical with diffraction peaks centered at $2 \theta$ of $18.7^{\circ}, 30.9^{\circ}, 36.5^{\circ}, 44.5^{\circ}$, $59.0^{\circ}$, and $64.7^{\circ}$. The diffraction peaks for $\mathrm{Zn}-\mathrm{Ni}-\mathrm{Co}$ oxide/Co-CX are slightly shifted and there is higher intensity of (400) plane at $2 \theta$ of $44.5^{\circ}$ which indicating the formation of zinc/nickel codoped $\mathrm{Co}_{3} \mathrm{O}_{4}$ on the carbon xerogel ${ }^{12}$. 


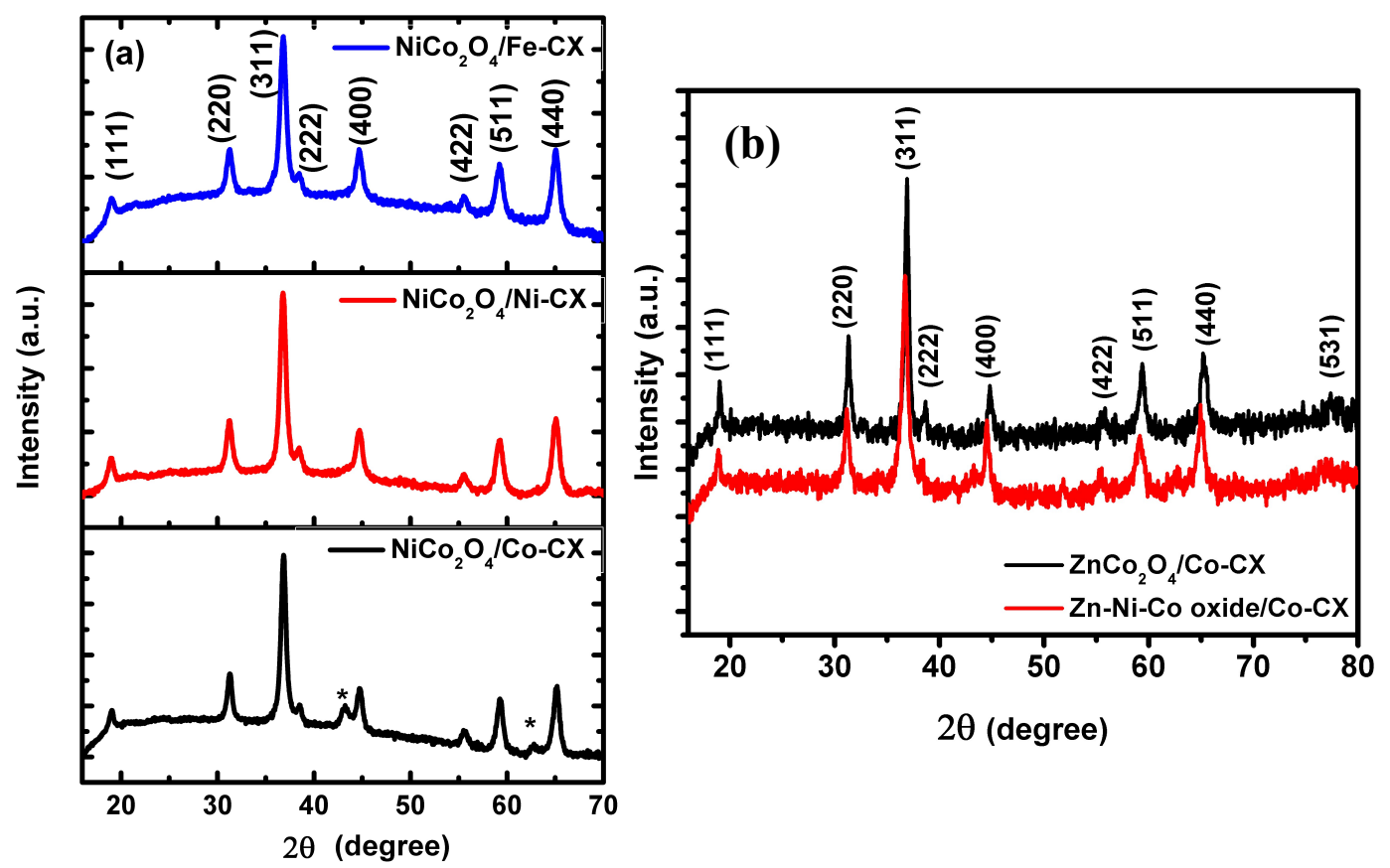

Figure 2: XRD pattern for the as prepared samples.

The mean particle size for the prepared sample is calculated by applying Scherrer equation to the XRD patterns, Table 2. Nickel cobaltite functionalized carbon xerogel have similar particle size ranging between $21.1-25.5 \mathrm{~nm}$. There is an increase in the particle size to $39.2 \mathrm{~nm}$ and $38.8 \mathrm{~nm}$ when carbon xerogel was doped with zinc cobaltite and Zn-Ni-Co oxide, respectively.

Table 2. Mean particle size obtained from applying Scherrer equation to XRD patterns.

\begin{tabular}{cc}
\hline Sample & $\boldsymbol{d}_{\text {Xrd }}(\mathbf{n m})$ \\
\hline $\mathrm{NiCo}_{2} \mathrm{O}_{4} / \mathrm{Co}-\mathrm{CX}$ & 25.5 \\
$\mathrm{NiCo}_{2} \mathrm{O}_{4} / \mathrm{Ni}-\mathrm{CX}$ & 24.1 \\
$\mathrm{NiCo}_{2} \mathrm{O}_{4} / \mathrm{Fe}-\mathrm{CX}$ & 21.1 \\
$\mathrm{ZnCo}_{2} \mathrm{O}_{4} / \mathrm{Co}-\mathrm{CX}$ & 39.2 \\
Zn-Ni-Co oxide/Co-CX & 38.8 \\
\hline
\end{tabular}


Samples morphology was characterized using scanning electron microscopy (SEM), Fig. 3. SEM images for all as-obtained samples clearly show that the samples are composed of 3D nanobundles with different lengths ${ }^{31-32}$. The nanobundle structure of the prepared samples is also confirmed with TEM analysis Fig. 4, with homogeneously anchoring of nanobundles on the surface of carbon xerogels (Fig. 4a-e). In addition, the nanobundles have different widths which is wider in case of $\mathrm{ZnCo}_{2} \mathrm{O}_{4} / \mathrm{Co}-\mathrm{CX}$ (Fig. $4 \mathrm{~d}$ ).
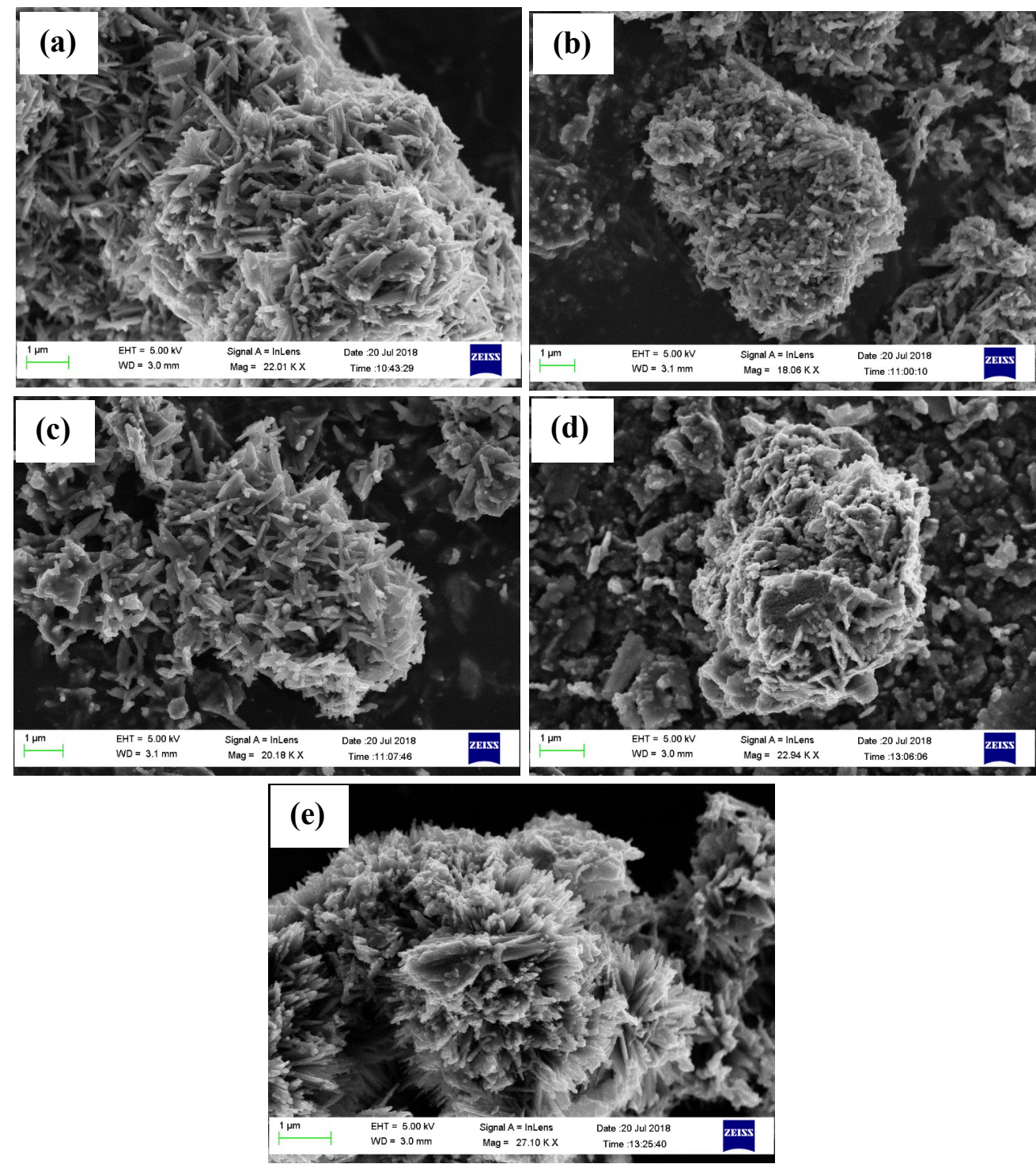

Figure 3: SEM images for (a) $\mathrm{NiCo}_{2} \mathrm{O}_{4} / \mathrm{Co}-\mathrm{CX}$, (b) $\mathrm{NiCo}_{2} \mathrm{O}_{4} / \mathrm{Ni}-\mathrm{CX}$, (c) $\mathrm{NiCo}_{2} \mathrm{O}_{4} / \mathrm{Fe}-\mathrm{CX}$, (d) $\mathrm{ZnCo}_{2} \mathrm{O}_{4} / \mathrm{Co}-\mathrm{CX}$, and (e) $\mathrm{Zn}-\mathrm{Ni}-\mathrm{Co} / \mathrm{Co}-\mathrm{CX}$. 
Also, Fig. $4 b$, shows that the $\mathrm{NiCo}_{2} \mathrm{O}_{4}$ nanobundles are composed of many small nanoparticles of $10-20 \mathrm{~nm}$ in diameter. Indicating that the prepared nanobundles are porous nanobundles instead of single crystal nanobundle.

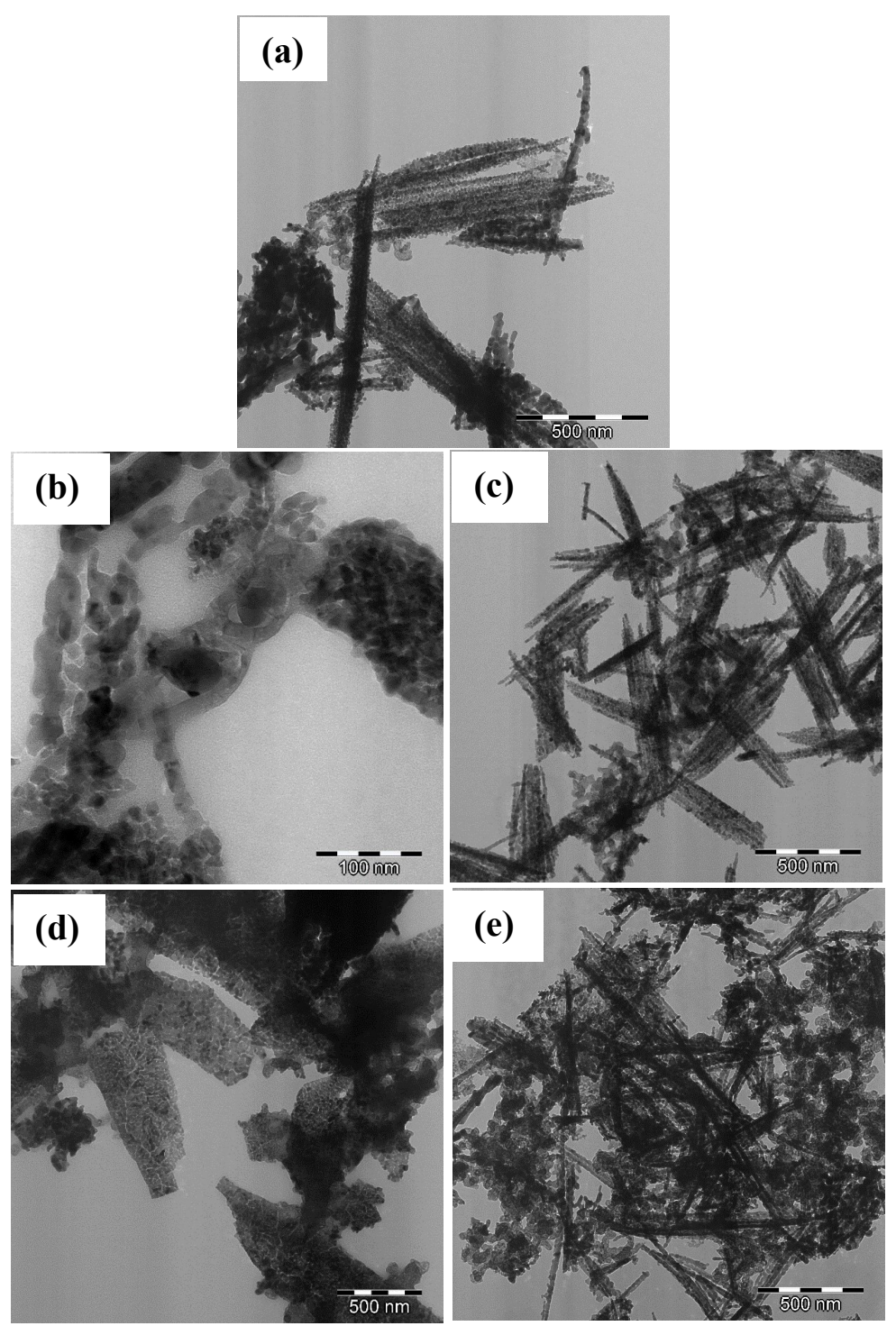

Figure 4: TEM images for (a) $\mathrm{NiCo}_{2} \mathrm{O}_{4} / \mathrm{Co}-\mathrm{CX}$, (b) $\mathrm{NiCo}_{2} \mathrm{O}_{4} / \mathrm{Ni}-\mathrm{CX}$, (c) $\mathrm{NiCo}_{2} \mathrm{O} 4 / \mathrm{Fe}-\mathrm{CX}$, (d) $\mathrm{ZnCo}_{2} \mathrm{O}_{4} / \mathrm{Co}-\mathrm{CX}$, and (e) $\mathrm{Zn}-\mathrm{Ni}-\mathrm{Co} / \mathrm{Co}-\mathrm{CX}$. 
Table 3, shows the XP spectra binding energies (B.E) of carbon, oxygen and nitrogen atoms. In which the lowest binding energy of oxygen $(\mathrm{O} 1 \mathrm{~s})$ at B.E of $529.3 \pm 0.3 \mathrm{eV}$ is compatible to oxygen bonded to transition metal cations with oxidation states of +2 and $+3{ }^{33}$.

Table 3. Binding energies of $\mathrm{C} 1 \mathrm{~s}, \mathrm{O} 1 \mathrm{~s}$, and $\mathrm{N} 1 \mathrm{~s}$ regions.

\begin{tabular}{ccccccc}
\hline Sample & $\begin{array}{c}\mathrm{C} 1 \mathrm{~s} \\
\text { eV }\end{array}$ & $\begin{array}{c}\text { FWHM } \\
\text { eV }\end{array}$ & $\begin{array}{c}\text { peak } \\
\%\end{array}$ & $\begin{array}{c}\text { O1s } \\
\text { eV }\end{array}$ & $\begin{array}{c}\text { peak } \\
\%\end{array}$ & $\begin{array}{c}\mathrm{N} 1 \mathrm{~s} \\
\mathrm{eV}\end{array}$ \\
\hline $\mathrm{NiCo}_{2} \mathrm{O}_{4} / \mathrm{Co}-\mathrm{CX}$ & 284.6 & 1.4 & 70.9 & 529.3 & 36.7 & 399.3 \\
& 285.7 & & 8.9 & 530.7 & 24.7 & 400.7 \\
& 286.3 & & 9.7 & 531.8 & 23.3 & \\
& 288.5 & & 10.4 & 533.2 & 15.3 & \\
\hline $\mathrm{NiCo}_{2} \mathrm{O}_{4} / \mathrm{Ni}-\mathrm{CX}$ & 284.6 & 1.4 & 67.5 & 529.1 & 34.9 & 398.9 \\
& 285.6 & & 11.0 & 530.7 & 27.8 & 400.4 \\
& 286.4 & & 10.4 & 531.8 & 22.4 & \\
& 288.5 & & 11.1 & 533.2 & 14.9 & \\
\hline $\mathrm{NiCo}_{2} \mathrm{O}_{4} / \mathrm{Fe}-\mathrm{CX}$ & 284.6 & 1.4 & 70 & 529.2 & 28 & 399.3 \\
& 285.8 & & 11 & 530.6 & 22 & 400.7 \\
& 286.6 & & 8 & 531.8 & 28 & \\
\hline $\mathrm{ZnCo} 2 \mathrm{O}_{4} / \mathrm{Co}-\mathrm{CX}$ & 288.6 & & 11 & 533.2 & 22 & \\
& 284.6 & 1.1 & 65 & 529.6 & 55 & 399.3 \\
& 285.4 & & 16 & 530.6 & 23 & 400.7 \\
& 286.4 & & 13 & 531.7 & 16 & \\
\hline $\mathrm{Zn}-\mathrm{Ni}_{-}-\mathrm{Co} / \mathrm{Co}-\mathrm{CX}$ & 288.5 & & 7 & 533.2 & 6 & \\
& 284.5 & 1.2 & 61 & 529.2 & 46 & 399.3 \\
& 285.4 & & 18 & 530.7 & 25 & 400.3 \\
& 286.4 & & 12 & 531.8 & 18 & \\
\hline
\end{tabular}

On the other hand, Table 4 shows the XP spectra binding energies (B.E) of the metal atoms. In analyzing Co2p, Fig. 5a, different Co2p $3 / 2$ peaks are obtained and assigned as following. In case of $\mathrm{NiCo}_{2} \mathrm{O}_{4}$ based samples the signals at $779.2 \pm 0.1$ correspond to $\mathrm{Co}^{2+}$ situated in octahedral holes whereas the signals at $780.6 \pm 0.2$ correspond to $\mathrm{Co}^{3+}$ situated in tetrahedral holes ${ }^{34-35}$. On the other hand, the XPS spectra of Ni2p region, Fig. $5 b$, show signals centered at $854.2 \pm 0.1$ and $871.7 \pm 0.2 \mathrm{eV}$ for $2 \mathrm{p}_{3 / 2}$ and $2 \mathrm{p}_{1 / 2}$, components respectively, which correspond to $\mathrm{Ni}^{2+}$ species, as 
well as signals at $855.9 \pm 0.3$ and $873.5 \pm 0.2 \mathrm{eV}$ corresponding to $\mathrm{Ni}^{3+}$ cations ${ }^{35}$. Iron was not detected in any sample by XPS, and Fig. 5c shows the Zn2p spectra. The presence of zinc cobaltite, $\mathrm{ZnCo}_{2} \mathrm{O}_{4}$, is confirmed by a peak centered at $1020.7 \mathrm{eV}{ }^{36}$, while the peak at 1021.5 $\mathrm{eV}-1021.8 \mathrm{eV}$ is assigned to $\mathrm{ZnO}{ }^{37}$.
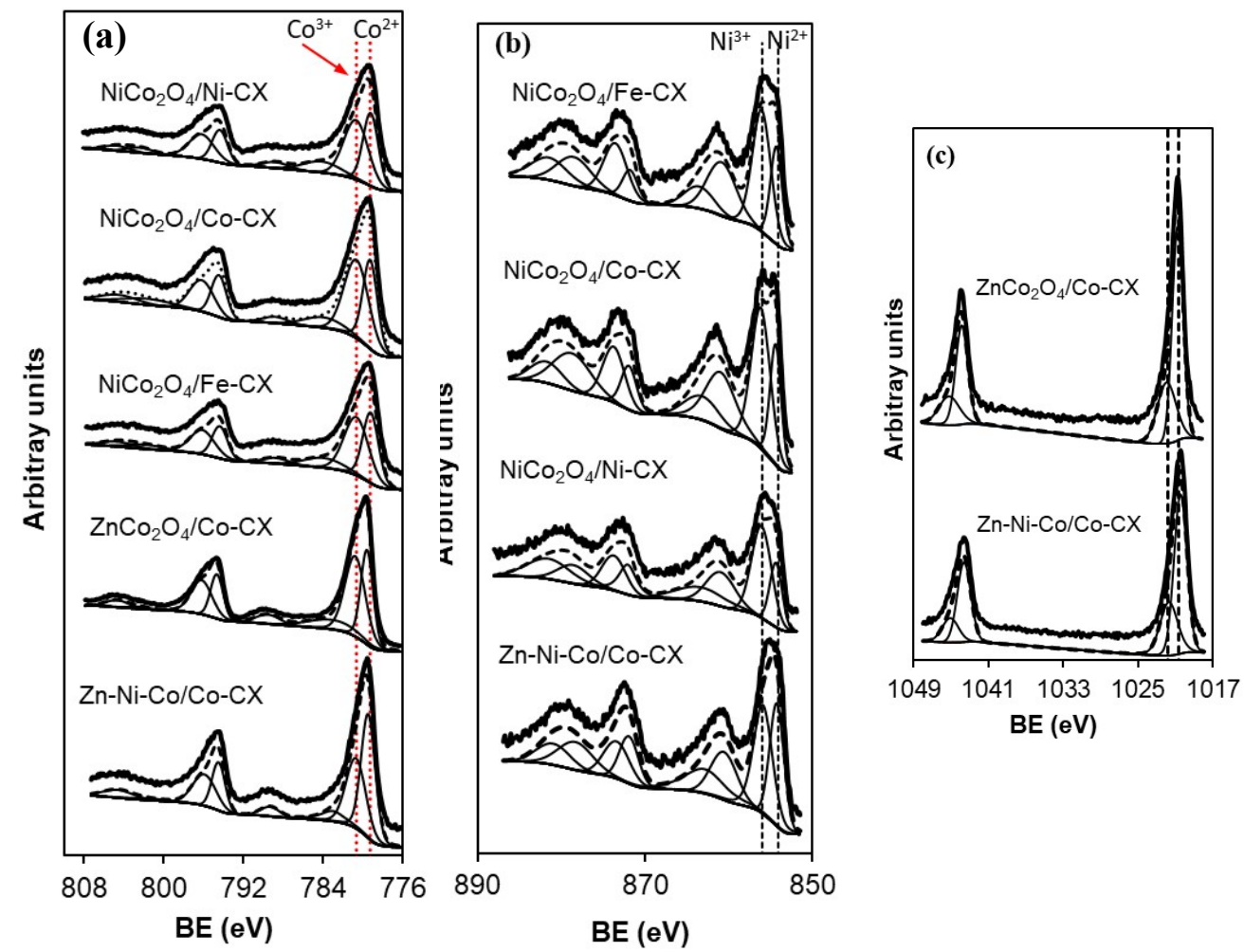

Figure 5: Deconvolution of XP spectra for Co2p, Ni2p and Zn2p regions.

Table 4. Binding energies of Co2p, Ni2p, and $\mathrm{Zn} 2 \mathrm{p}$ regions.

\begin{tabular}{ccccccc}
\hline Sample & $\begin{array}{c}\mathrm{Co} 2 \mathrm{p}_{3 / 2} \\
\mathrm{eV}\end{array}$ & $\begin{array}{c}\text { peak } \\
\%\end{array}$ & $\begin{array}{c}\mathrm{Ni} 2 \mathrm{p}_{3 / 2} \\
\mathrm{eV}\end{array}$ & $\begin{array}{c}\text { peak } \\
\%\end{array}$ & $\begin{array}{c}\mathrm{Zn} 2 \mathrm{p}_{3 / 2} \\
\mathrm{eV}\end{array}$ & $\begin{array}{c}\text { Peak } \\
\%\end{array}$ \\
\hline $\mathrm{NiCo}_{2} \mathrm{O}_{4} / \mathrm{Co}-\mathrm{CX}$ & 779.2 & 43.0 & 854.3 & 34.4 & & \\
& 780.6 & 57.0 & 856.1 & 65.6 & & \\
& 783.9 & & 860.9 & & & \\
& 788.8 & & 863.2 & & & \\
& 794.4 & & 871.9 & & & \\
& 796.2 & & 873.7 & & & \\
& 801.6 & & 878.7 & & & \\
\hline
\end{tabular}




\begin{tabular}{|c|c|c|c|c|c|c|}
\hline \multirow[t]{8}{*}{$\mathrm{NiCo}_{2} \mathrm{O}_{4} / \mathrm{Ni}-\mathrm{CX}$} & 779.2 & 43.7 & 854.2 & 32.3 & & \\
\hline & 780.6 & 56.3 & 856.0 & 67.7 & & \\
\hline & 784.1 & & 860.8 & & & \\
\hline & 788.8 & & 863.5 & & & \\
\hline & 794.4 & & 871.7 & & & \\
\hline & 796.2 & & 873.5 & & & \\
\hline & 802.4 & & 878.5 & & & \\
\hline & 804.8 & & 881.5 & & & \\
\hline \multirow[t]{8}{*}{$\mathrm{NiCo}_{2} \mathrm{O}_{4} / \mathrm{Fe}-\mathrm{CX}$} & 779.2 & 43.9 & 854.3 & 35.5 & & \\
\hline & 780.6 & 56.1 & 856.0 & 64.5 & & \\
\hline & 783.9 & & 860.9 & & & \\
\hline & 788.7 & & 863.4 & & & \\
\hline & 794.4 & & 872.0 & & & \\
\hline & 796.1 & & 873.7 & & & \\
\hline & 801.8 & & 878.5 & & & \\
\hline & 804.7 & & 881.5 & & & \\
\hline \multirow[t]{8}{*}{$\mathrm{ZnCo}_{2} \mathrm{O}_{4} / \mathrm{Co}-\mathrm{CX}$} & 779.5 & 41.9 & & & 1020.7 & 67.0 \\
\hline & 780.7 & 58.1 & & & 1021.9 & 33.0 \\
\hline & 783.0 & & & & & \\
\hline & 789.5 & & & & & \\
\hline & 794.7 & & & & & \\
\hline & 796.2 & & & & & \\
\hline & 802.4 & & & & & \\
\hline & 804.7 & & & & & \\
\hline \multirow[t]{8}{*}{$\mathrm{Zn}-\mathrm{Ni}-\mathrm{Co} / \mathrm{Co}-\mathrm{CX}$} & 779.4 & 53.0 & 854.2 & 45.3 & 1020.5 & 67.7 \\
\hline & 780.7 & 47.0 & 855.8 & 54.7 & 1021.8 & 32.3 \\
\hline & 783.0 & & 860.5 & & & \\
\hline & 789.3 & & 862.8 & & & \\
\hline & 794.5 & & 871.9 & & & \\
\hline & 795.9 & & 873.4 & & & \\
\hline & 801.2 & & 878.3 & & & \\
\hline & 804.6 & & 880.9 & & & \\
\hline
\end{tabular}

Finally, Table 5 collects the superficial chemical composition of the samples. The nitrogen content of the external surface is extremely low in all the samples. Besides, it should be remarked that $\mathrm{Zn}$ containing samples have the highest total metal concentration in the external 
surface area and part of the oxygen content can be due to the calcination treatment during the preparation of the samples.

Table 5. Surface chemical composition in wt. \% obtain by XPS.

\begin{tabular}{ccccccc}
\hline Sample & $\mathrm{C}$ & $\mathrm{O}$ & $\mathrm{N}$ & $\mathrm{Co}$ & $\mathrm{Ni}$ & $\mathrm{Zn}$ \\
\hline $\mathrm{NiCo}_{2} \mathrm{O}_{4} / \mathrm{Co}-\mathrm{CX}$ & 37.3 & 28.8 & 0.2 & 21.6 & 12.1 & 0.0 \\
$\mathrm{NiCo}_{2} \mathrm{O}_{4} / \mathrm{Ni}-\mathrm{CX}$ & 40.3 & 29.6 & 0.2 & 18.7 & 11.2 & 0.0 \\
$\mathrm{NiCo}_{2} \mathrm{O}_{4} / \mathrm{Fe}-\mathrm{CX}$ & 46.8 & 27.4 & 0.1 & 17.5 & 8.2 & 0.0 \\
$\mathrm{ZnCo}_{2} \mathrm{O}_{4} / \mathrm{Co}-\mathrm{CX}$ & 20.0 & 30.7 & 0.2 & 41.7 & 0.0 & 7.4 \\
$\mathrm{Zn}-\mathrm{Ni}-\mathrm{Co} / \mathrm{Co}-\mathrm{CX}$ & 28.5 & 28.5 & 0.2 & 21.5 & 11.6 & 9.7 \\
\hline
\end{tabular}

\subsection{Oxygen reduction reaction activity}

Samples performance in presence and absence of oxygen was studied using cyclic voltammetry in oxygen and nitrogen saturated electrolyte $(0.1 \mathrm{M} \mathrm{KOH})$, respectively. Fig. 6a shows the behavior of $\mathrm{NiCo}_{2} \mathrm{O}_{4} / \mathrm{Co}-\mathrm{CX}$ sample in saturated oxygen and nitrogen electrolyte at scan rate of $50 \mathrm{mV} \cdot \mathrm{s}^{-1}$. The figure shows the presence of oxygen reduction peak indicating the activity of the used material for ORR. Also, there are couple of redox peaks (I/II) at positive potential range, these peaks come from the reversible transition between $\mathrm{Co}_{3} \mathrm{O}_{4}$ and $\mathrm{CoOOH}^{38}$. This reaction can be formulated as $\mathrm{Co}_{3} \mathrm{O}_{4}+\mathrm{OH}^{-}+\mathrm{H}_{2} \mathrm{O} \leftrightarrow 3 \mathrm{CoOOH}+\mathrm{e}^{-}$.

Regarding studying the effect of the dopant metal $(\mathrm{M}=\mathrm{Co}, \mathrm{Ni}, \mathrm{Fe})$ on the activity of carbon xerogels toward ORR, the three doped samples functionalized with $\mathrm{NiCo}_{2} \mathrm{O}_{4}$ were tested as electrocatalysts for ORR, Fig. 6b. The results show that the electrochemical performance towards ORR is higher for cobalt doped carbon xerogels (Co-CX) followed by samples doped with iron (Fe) and nickel (Ni) which is in a good agreement with previous published work 28,39 . 
In general incorporation of transition metal into the carbon structure promotes the catalytic activity for ORR due to the generation of more active sites ${ }^{40}$. Related work attributed the lower activity of nickel doped carbon electrocatalysts to the formation of a nickel oxide $\mathrm{NiO}$ on the carbon surface which has inhibitory effect on the catalytic current and a poisoning effect on the ORR activity ${ }^{41}$. Another work explains the higher activity of cobalt based carbon for ORR to the formation of cobalt-nitrogen $(\mathrm{Co}-\mathrm{N})$ complexes during the pyrolysis under nitrogen in the preparation of carbon, these Co-N complexes moieties have a strong activity for ORR ${ }^{42}$.
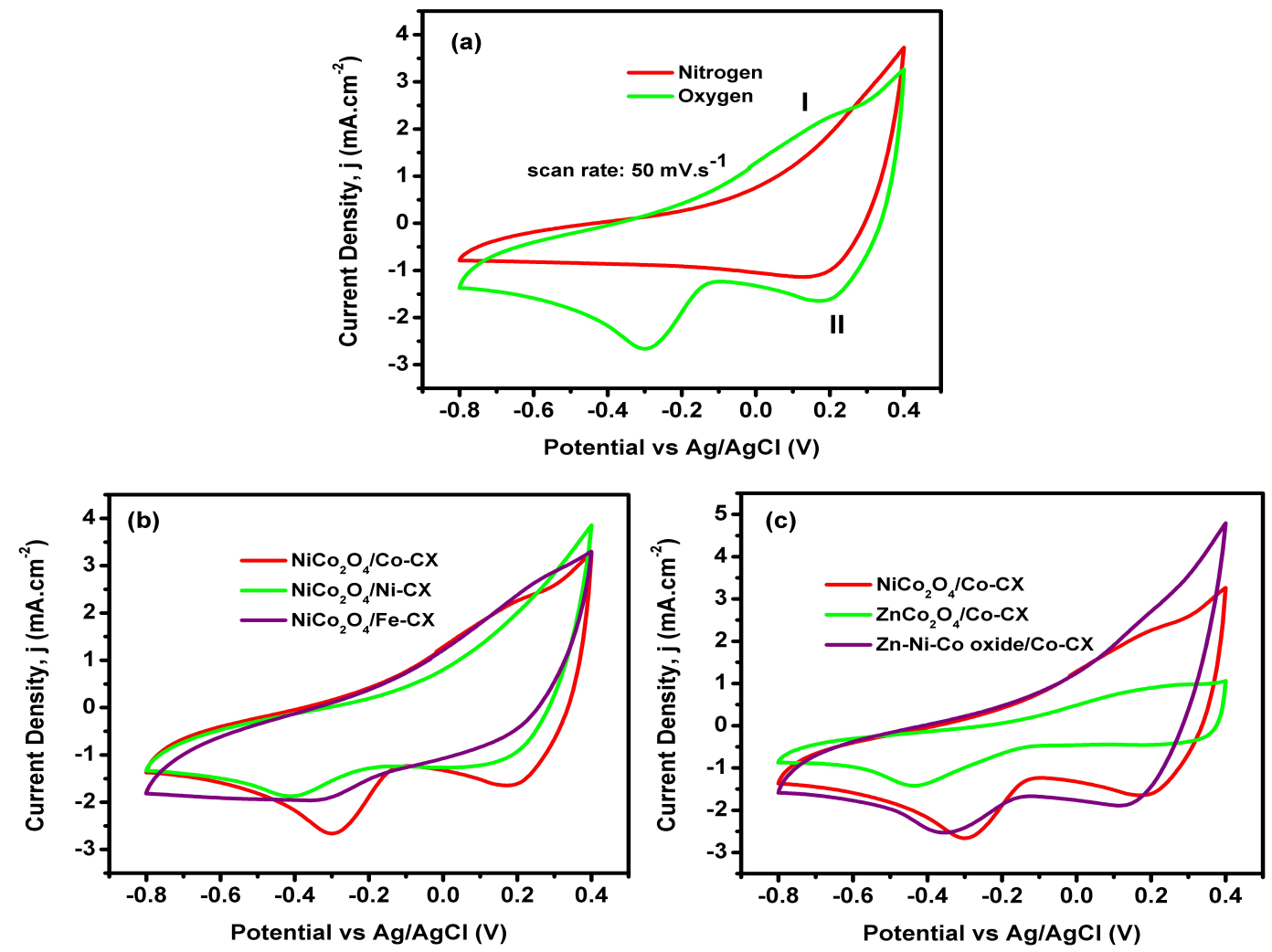

Figure 6: cyclic voltammograms (CV) of (a) $\mathrm{NiCo}_{2} \mathrm{O}_{4} / \mathrm{Co}-\mathrm{CX}$ in both nitrogen and oxygen saturated electrolyte, (b) $\mathrm{NiCo}_{2} \mathrm{O}_{4} / \mathrm{M}-\mathrm{CX}$ and (c) $\mathrm{NiCo}_{2} \mathrm{O}_{4} / \mathrm{Co}-\mathrm{CX}, \mathrm{ZnCo}_{2} \mathrm{O}_{4} / \mathrm{Co}-\mathrm{CX}, \mathrm{Zn}-\mathrm{Ni}-\mathrm{Co}$ oxide/Co-CX in oxygen saturated electrolyte. 
In order to study the effect of functionalized metal oxide, two binary transition metal oxides (i.e. $\mathrm{NiCo}_{2} \mathrm{O}_{4}$ and $\mathrm{ZnCo}_{2} \mathrm{O}_{4}$ ) and one ternary metal oxide ( $\mathrm{Zn}-\mathrm{Ni}$-Co oxide) functionalized over cobalt doped carbon xerogel (Co-CX) were tested, Fig. 6c. Among all samples being $\mathrm{NiCo}_{2} \mathrm{O}_{4} / \mathrm{Co}-\mathrm{CX}$ the one that has the highest electrochemical performance to ORR followed by Zn-Ni-Co oxide $/ \mathrm{Co}-\mathrm{CX}$ and $\mathrm{ZnCo}_{2} \mathrm{O}_{4} / \mathrm{Co}-\mathrm{CX}$. These results are also confirmed with the data obtained from Linear Sweep Voltammetry (LSV). The LSV for $\mathrm{NiCo}_{2} \mathrm{O}_{4} / \mathrm{Co}-\mathrm{CX}$ was carried out using rotating desk electrode with different speeds (Fig. 7a). The estimated number of electrons transferred at a given potential obtained from Koutecky-Levich Equation are compiled in Table 6. The data obtained from LSV for the prepared electrocatalysts also confirms that, carbon xerogel doped with cobalt has the highest electrochemical performance to ORR (Fig. 7b) and $\mathrm{NiCo}_{2} \mathrm{O}_{4}$ functionalized carbon xerogel is the better electrocatalyst (Fig. 7c).
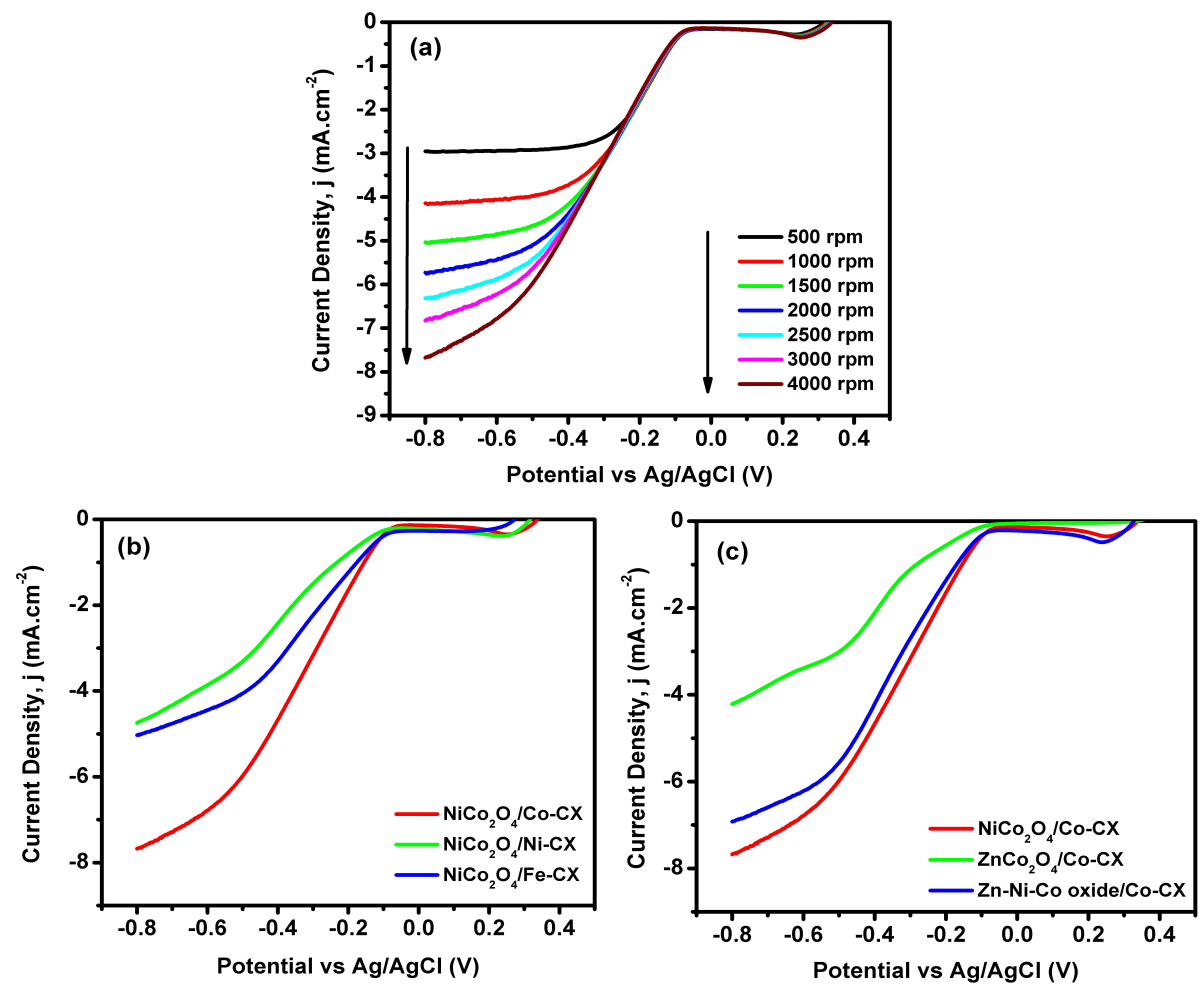
Figure 7: Linear sweep voltammograms (LSV) for (a) $\mathrm{NiCo}_{2} \mathrm{O}_{4} / \mathrm{Co}-\mathrm{CX}$ at $5 \mathrm{mV} \cdot \mathrm{s}^{-1}$ with different speeds from $500 \mathrm{rpm}$ to $4000 \mathrm{rpm}$, (b) Koutecky-Levich fits at different potentials: from -0.6 to $0.8 \mathrm{~V}$. (c,d) LSV for the prepared samples at $4000 \mathrm{rpm}$.

These results can be explained to the higher number of electrons transferred in these both samples. For example, in $\mathrm{NiCo}_{2} \mathrm{O}_{4} / \mathrm{Co}-\mathrm{CX}$ the oxygen reduction reaction occurs mainly through the $4 \mathrm{e}-$ transfer (Fig. 8a) with lower onset potential $\mathrm{E}_{\text {onset, }}$ Table 6 . However, in $\mathrm{NiCo}_{2} \mathrm{O}_{4} / \mathrm{Fe}-\mathrm{CX}$ and $\mathrm{NiCo}_{2} \mathrm{O}_{4} / \mathrm{Ni}-\mathrm{CX}$ the oxygen reduction reaction occurs through a combination of both $2 \mathrm{e}-$ and $4 \mathrm{e}-$, results in a value of $\mathrm{n}=3.6$ and 3.5 , for both respectively. Likewise, in comparison between different metal oxides being $\mathrm{NiCO}_{2} \mathrm{O}_{4}$ the one that undergoes the oxygen reduction reaction via the $4 \mathrm{e}-$ transfer (Fig. $8 \mathrm{~b}$ ). Besides, the number of electrons transferred has a direct relation and depend on the electrocatalyst resistance. The electrochemical impedance spectroscopy (EIS) is an important technique that determine the behavior of electrode in certain application and its resistance. Fig. 9 shows the Nyquist plots for the prepared electrodes. As it can be seen, a semicircle is observed at high frequency region due to charge transfer resistance on electrode/electrolyte interface. While at low frequency, a purely capacitive behavior is obtained and the combination between both resistive and capacitive behavior is known as Warburg region that has a relation to the diffusive resistance ${ }^{31,43}$. The equivalent series resistance of the electrode can be determined by the intersection of the semicircle with the real axis, Table 6. 
Table 6. Parameters obtained from LSV@ @ 4000 rpm (values of n refer to K-L fitting for data at $-0.8 \mathrm{~V}$ ) and ESR calculated from Nyquist plot.

\begin{tabular}{cccc}
\hline Sample & $\begin{array}{c}\mathbf{E}_{\text {onset }} \\
\mathbf{V}\end{array}$ & $\mathbf{n}$ & $\begin{array}{c}\text { ESR } \\
\Omega\end{array}$ \\
\hline $\mathrm{NiCo}_{2} \mathrm{O}_{4} / \mathrm{Co}-\mathrm{CX}$ & -0.06 & 4.0 & 2.74 \\
$\mathrm{NiCo}_{2} \mathrm{O}_{4} / \mathrm{Ni}-\mathrm{CX}$ & -0.07 & 3.5 & 6.18 \\
$\mathrm{NiCo}_{2} \mathrm{O}_{4} / \mathrm{Fe}-\mathrm{CX}$ & -0.07 & 3.6 & 3.90 \\
$\mathrm{ZnCo}_{2} \mathrm{O}_{4} / \mathrm{Co}-\mathrm{CX}$ & -0.09 & 3.4 & 4.63 \\
$\mathrm{Zn}-\mathrm{Ni}-\mathrm{Co} / \mathrm{Co}-\mathrm{CX}$ & -0.06 & 3.5 & 1.80 \\
\hline
\end{tabular}

In Nyquist plots for doped carbon xerogel (Fig. 9a), the diameter of the semicircle for $\mathrm{NiCo}_{2} \mathrm{O}_{4} / \mathrm{Co}-\mathrm{CX}$ is lower than that for $\mathrm{NiCo}_{2} \mathrm{O}_{4} / \mathrm{Fe}-\mathrm{CX}$ or $\mathrm{NiCo}_{2} \mathrm{O}_{4} / \mathrm{Ni}-\mathrm{CX}$ indicating lower charge-transfer resistance $\left(\mathrm{R}_{\mathrm{ct}}\right)$ between electrode and electrolyte interface. Moreover, the lowest equivalent series resistance (ESR) is obtained for $\mathrm{NiCo}_{2} \mathrm{O}_{4} / \mathrm{Co}-\mathrm{CX}$ which means better conductivity for that electrocatalyst.
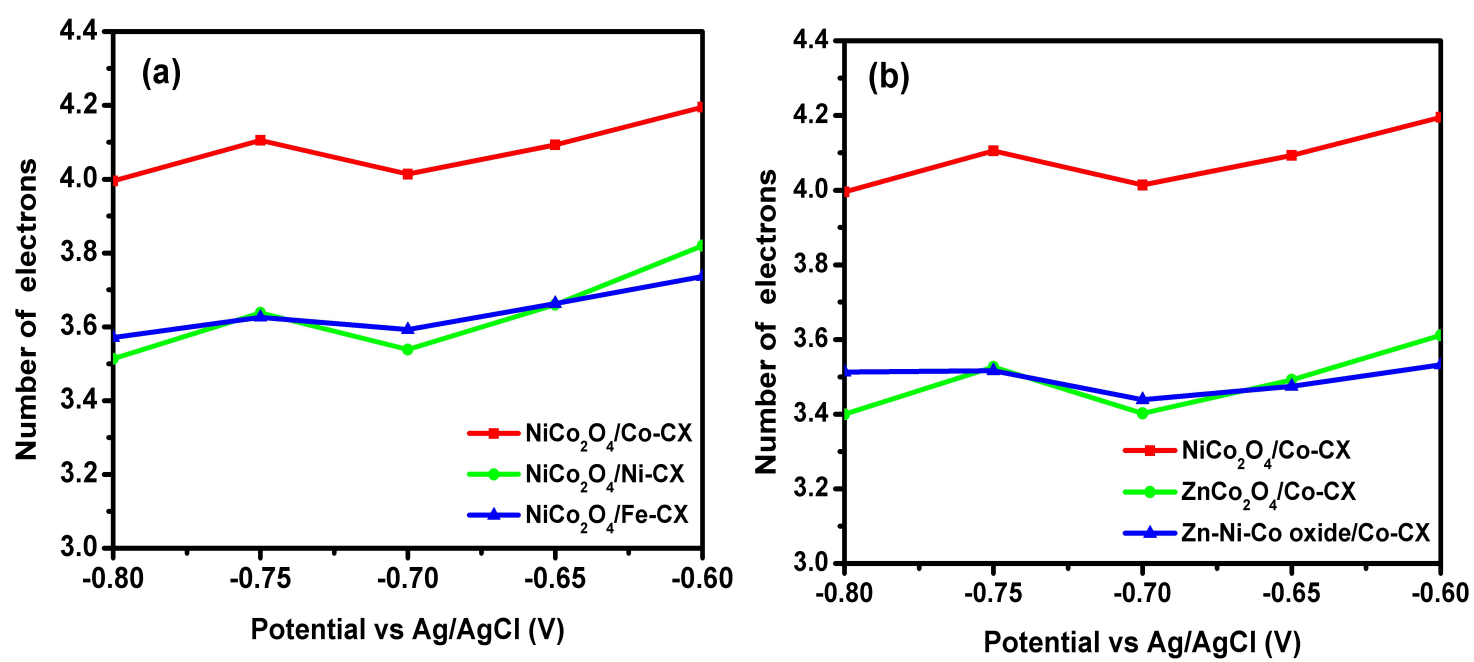

Figure 8: Variation of number of electron transferred with $\mathrm{E}$ vs $\mathrm{Ag} / \mathrm{AgCl}$. 
Similar results obtained in comparing metal oxides activity to ORR, for $\mathrm{NiCo}_{2} \mathrm{O}_{4}$ and $\mathrm{Zn}-\mathrm{Ni}-\mathrm{Co}$ oxide the diameter of the semicircle is similar indicating lower resistance between electrode/ electrolyte interface. Although the ESR of Zn-Ni-Co oxide is lower than that for $\mathrm{NiCo}_{2} \mathrm{O}_{4}$ that indicating better electronic conductivity, the vertical line of the capacitive part for $\mathrm{NiCo}_{2} \mathrm{O}_{4} / \mathrm{Co}-$ $\mathrm{CX}$ is more perpendicular to the $\mathrm{X}$-axis which means swift ion diffusion in electrolyte and good adsorption onto the electrode surface results in higher activity to ORR (Fig. 9b).
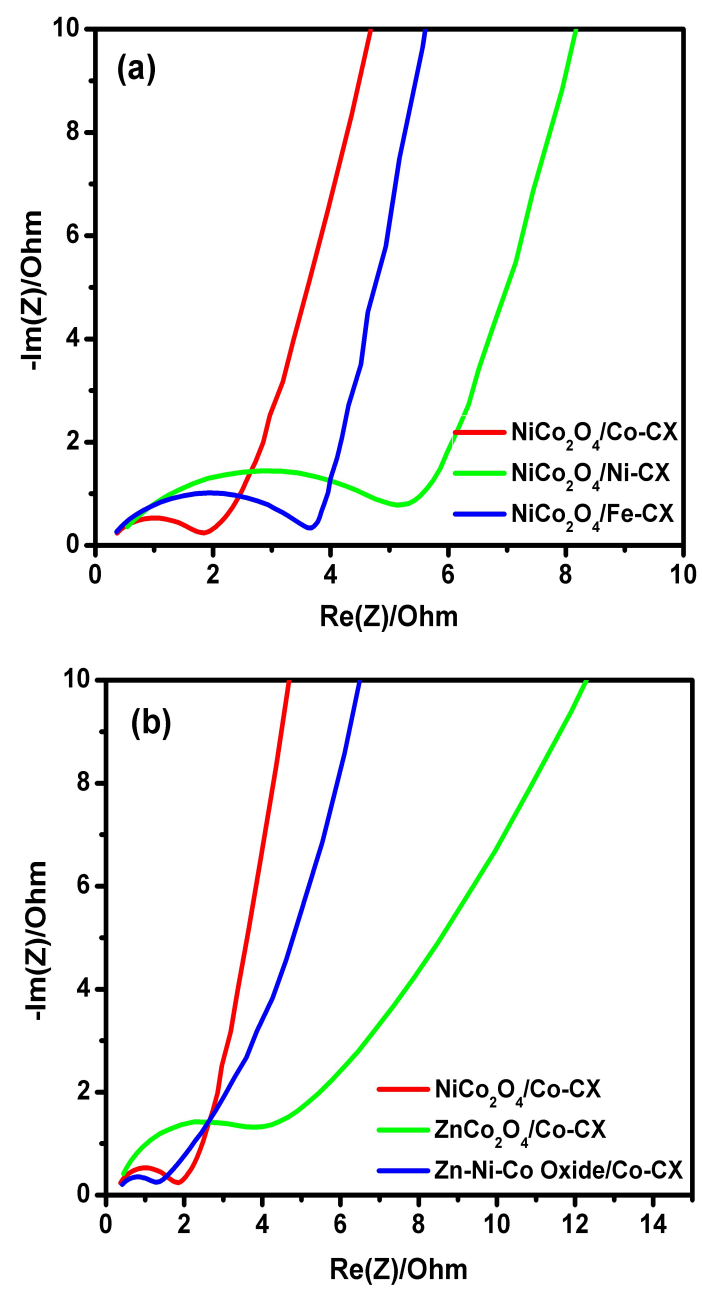

Figure 9: Nyquist plots obtained from EIS for the prepared samples. 
In any case, we expected a better electro-catalytic behavior of our ternary metal oxide samples, incorporating $\mathrm{Zn}$ to the metal phase; however, this has not occurred at least in the desirable extension. One plausible explanation can be due to the important increasing of the metal particle size when $\mathrm{Zn}$ is added, which besides avoids a good comparison of the electro-catalytic activity among all the samples. The available bibliography about a possible effect of the metal particle sizes on the ORR activity is not clear. Some works with Pt supported on carbon materials found a relation between the particle size and the specific activity towards ORR, however while some of them mention that for oxygen reduction a loss of catalytic activity with the decreased $\mathrm{Pt}$ particle size occurs due to the stronger adsorption of oxygenated species ${ }^{10,44}$, other authors found an optimal Pt particle size ${ }^{45}$. Nevertheless, with Fe, Co or Ni based catalysts the previous mentioned tendencies seem to be different, where the small sized cobalt nanoparticles and dispersion in carbon provide fast electron transport between the carbon matrix and the cobalt nanoparticles, leading to efficient electrical conductivity 11,46 . This explanation is also in agreement with our results where the extremely large main crystallite sizes of samples containing $\mathrm{Zn}$, in relation with the free $\mathrm{Zn}$ samples, can not only justify their comparative electro-catalytic behavior but also show them as very attractive active phase for ORR, whose metal sizes should be better controlled and be optimized for future applications.

\section{Conclusions}

$\mathrm{NiCo}_{2} \mathrm{O}_{4}, \mathrm{ZnCo}_{2} \mathrm{O}_{4}$, and $\mathrm{Zn}$-Ni-Co oxide nanobundles were homogeneously developed on the carbon xerogel surface by hydrothermal method. The type of carbon xerogel dopant plays an important role in ORR activity being cobalt doped carbon xerogels the one that has higher electrochemical activity to ORR than $\mathrm{Fe}$ or $\mathrm{Ni}$. The $\mathrm{NiCo}_{2} \mathrm{O}_{4} / \mathrm{Co}-\mathrm{CX}$ nanobundle has excellent activity to oxygen reduction reaction. This activity comes from its lower equivalent series 
resistance which increases the number of ions reaching the electrode surface beside good adsorption of electrolytic ions onto its surface. The lower onset potential for $\mathrm{NiCo}_{2} \mathrm{O}_{4} / \mathrm{Co}-\mathrm{CX}$ together with its higher current densities leads that $\mathrm{NiCo}_{2} \mathrm{O}_{4} / \mathrm{Co}-\mathrm{CX}$ nanobundles to be very attractive electrodes for ORR. Despite $\mathrm{Zn}-\mathrm{Ni}-\mathrm{Co}$ oxide/Co-CX has the lowest equivalent series resistance indicating higher electronic conductivity; its reduction in the mesopore volume could be able to reduce the ionic diffusion and adsorption decreasing its activity for ORR. However, the extremely large main crystallite sizes of samples containing $\mathrm{Zn}$, in relation with the other samples, avoid a good comparison of the electro-catalytic activity among of the samples. The role of $\mathrm{Zn}$ in this type of transition metal oxides nanobundles based ORR catalysts cannot be underestimated, and a future work in which this parameter can be better controlled is necessary to obtain coherent conclusions.

\section{Acknowledgments}

The authors greatly acknowledge the financial support from STDF funds with ID no STF-25402, the grant RNM-172 (Junta de Andalucía).

\section{References}

1. Hoogers, G., Fuel Cell Technology Handbook; CRC Press, 2003, p P. 4-23.

2. Carrette, L.; Friedrich, K. A.; Stimming, U., Fuel Cells: Principles, Types, Fuels, and Applications. ChemPhysChem 2000, 1, 162-193.

3. Rowley-Neale, S. J.; Fearn, J. M.; Brownson, D. A.; Smith, G. C.; Ji, X.; Banks, C. E., 2d Molybdenum Disulphide $\left(2 \mathrm{~d}-\mathrm{MoS}_{2}\right)$ Modified Electrodes Explored Towards the Oxygen Reduction Reaction. Nanoscale 2016, 8, 14767-14777. 
4. Wang, B., Recent Development of Non-Platinum Catalysts for Oxygen Reduction Reaction. Journal of Power Sources 2005, 152, 1-15.

5. Gara, M.; Compton, R. G., Activity of Carbon Electrodes Towards Oxygen Reduction in Acid: A Comparative Study. New Journal of Chemistry 2011, 35, 2647-2652.

6. Liu, Y.; Yue, X.; Li, K.; Qiao, J.; Wilkinson, D. P.; Zhang, J., Pem Fuel Cell Electrocatalysts Based on Transition Metal Macrocyclic Compounds. Coordination Chemistry Reviews 2016, 315, 153-177.

7. Randviir, E. P.; Banks, C. E., The Oxygen Reduction Reaction at Graphene Modified Electrodes. Electroanalysis 2014, 26, 76-83.

8. Banham, D.; Ye, S.; Pei, K.; Ozaki, J.-i.; Kishimoto, T.; Imashiro, Y., A Review of the Stability and Durability of Non-Precious Metal Catalysts for the Oxygen Reduction Reaction in Proton Exchange Membrane Fuel Cells. Journal of Power Sources 2015, 285, 334-348.

9. Paulus, U.; Wokaun, A.; Scherer, G.; Schmidt, T.; Stamenkovic, V.; Radmilovic, V.; Markovic, N.; Ross, P., Oxygen Reduction on Carbon-Supported Pt-Ni and Pt-Co Alloy Catalysts. The Journal of Physical Chemistry B 2002, 106, 4181-4191.

10. Takasu, Y.; Ohashi, N.; Zhang, X.-G.; Murakami, Y.; Minagawa, H.; Sato, S.; Yahikozawa, K., Size Effects of Platinum Particles on the Electroreduction of Oxygen. Electrochimica Acta 1996, 41, 2595-2600.

11. Liu, Y.; Jiang, H.; Zhu, Y.; Yang, X.; Li, C., Transition Metals (Fe, Co, and Ni) Encapsulated in Nitrogen-Doped Carbon Nanotubes as Bi-Functional Catalysts for Oxygen Electrode Reactions. Journal of Materials Chemistry A 2016, 4, 1694-1701.

12. Zhang, Q.; Xu, W.; Sun, J.; Pan, Z.; Zhao, J.; Wang, X.; Zhang, J.; Man, P.; Guo, J.; Zhou, Z. J. N. 1., Constructing Ultrahigh-Capacity Zinc-Nickel-Cobalt Oxide@ Ni(OH) 2 Core- 
Shell Nanowire Arrays for High-Performance Coaxial Fiber-Shaped Asymmetric Supercapacitors. 2017, 17, 7552-7560.

13. Prabu, M.; Ketpang, K.; Shanmugam, S., Hierarchical Nanostructured $\mathrm{NiCo}_{2} \mathrm{O}_{4}$ as an Efficient Bifunctional Non-Precious Metal Catalyst for Rechargeable Zinc-Air Batteries. Nanoscale 2014, 6, 3173-3181.

14. Carriazo, D.; Patiño, J.; Gutiérrez, M. C.; Ferrer, M. L.; del Monte, F., MicrowaveAssisted Synthesis of $\mathrm{NiCo}_{2} \mathrm{O}_{4}-$ Graphene Oxide Nanocomposites Suitable as Electrodes for Supercapacitors. RSC Advances 2013, 3, 13690-13695.

15. Wang, X.; Han, X.; Lim, M.; Singh, N.; Gan, C. L.; Jan, M.; Lee, P. S., Nickel Cobalt Oxide-Single Wall Carbon Nanotube Composite Material for Superior Cycling Stability and High-Performance Supercapacitor Application. The Journal of Physical Chemistry C 2012, 116, $12448-12454$.

16. Wang, J.; Wu, Z.; Han, L.; Lin, R.; Xin, H. L.; Wang, D., Hollow-Structured Carbon-Supported Nickel Cobaltite Nanoparticles as an Efficient Bifunctional Electrocatalyst for the Oxygen Reduction and Evolution Reactions. ChemCatChem 2016, 8, 736-742.

17. Pekala, R.; Alviso, C.; Kong, F.; Hulsey, S., Aerogels Derived from Multifunctional Organic Monomers. Journal of Non-Crystalline Solids 1992, 145, 90-98.

18. Pekala, R., Organic Aerogels from the Polycondensation of Resorcinol with Formaldehyde. Journal of Materials Science 1989, 24, 3221-3227.

19. Gesser, H.; Goswami, P., Aerogels and Related Porous Materials. Chemical Reviews 1989, $89,765-788$.

20. Al-Muhtaseb, S. A.; Ritter, J. A., Preparation and Properties of ResorcinolFormaldehyde Organic and Carbon Gels. Advanced Materials 2003, 15, 101-114. 
21. Maldonado-Hódar, F.; Ferro-Garcia, M.; Rivera-Utrilla, J.; Moreno-Castilla, C., Synthesis and Textural Characteristics of Organic Aerogels, Transition-Metal-Containing Organic Aerogels and Their Carbonized Derivatives. Carbon 1999, 37, 1199-1205.

22. Tamon, H.; Ishizaka, H.; Araki, T.; Okazaki, M., Control of Mesoporous Structure of Organic and Carbon Aerogels. Carbon 1998, 36, 1257-1262.

23. Bailón-García, E.; Carrasco-Marín, F.; Pérez-Cadenas, A. F.; Maldonado-Hódar, F. J., Development of Carbon Xerogels as Alternative Pt-Supports for the Selective Hydrogenation of Citral. Catalysis Communications 2015, 58, 64-69.

24. Abdelwahab, A.; Castelo-Quibén, J.; Pérez-Cadenas, M.; Maldonado-Hódar, F. J.; Carrasco-Marín, F.; Pérez-Cadenas, A. F., Insight of the Effect of Graphitic Cluster in the Performance of Carbon Aerogels Doped with Nickel as Electrodes for Supercapacitors. Carbon 2018, 139, 888-895.

25. Job, N.; Marie, J.; Lambert, S.; Berthon-Fabry, S.; Achard, P., Carbon Xerogels as Catalyst Supports for Pem Fuel Cell Cathode. Energy Conversion and Management 2008, 49, $2461-2470$.

26. EL-Deeb, M. M.; El Rouby, W. M.; Abdelwahab, A.; Farghali, A. A., Effect of Pore Geometry on the Electrocatalytic Performance of Nickel Cobaltite/Carbon Xerogel Nanocomposite for Methanol Oxidation. Electrochimica Acta 2018, 259, 77-85.

27. Wu, C.; Cai, J.; Zhang, Q.; Zhou, X.; Zhu, Y.; Shen, P. K.; Zhang, K. J. A. a. m.; interfaces, Hierarchical Mesoporous Zinc-Nickel-Cobalt Ternary Oxide Nanowire Arrays on Nickel Foam as High-Performance Electrodes for Supercapacitors. 2015, 7, 26512-26521.

28. Abdelwahab, A.; Castelo-Quibén, J.; Vivo-Vilches, J. F.; Pérez-Cadenas, M.; Maldonado-Hódar, F. J.; Carrasco-Marín, F.; Pérez-Cadenas, A. F., Electrodes Based on Carbon 
Aerogels Partially Graphitized by Doping with Transition Metals for Oxygen Reduction Reaction. Nanomaterials 2018, 8, 266.

29. Elmouwahidi, A.; Vivo-Vilches, J. F.; Pérez-Cadenas, A. F.; Maldonado-Hódar, F. J.; Carrasco-Marín, F., Free Metal Oxygen-Reduction Electro-Catalysts Obtained from Biomass Residue of the Olive Oil Industry. Chemical Engineering Journal 2016, 306, 1109-1115.

30. Wang, T.; Gao, D.; Zhuo, J.; Zhu, Z.; Papakonstantinou, P.; Li, Y.; Li, M., Size-Dependent Enhancement of Electrocatalytic Oxygen-Reduction and Hydrogen-Evolution Performance of $\mathrm{MoS}_{2}$ Particles. Chemistry-A European Journal 2013, 19, 11939-11948.

31. Wang, Z.; Zhang, X.; Zhang, Z.; Qiao, N.; Li, Y.; Hao, Z., Hybrids of Nico2o4 Nanorods and Nanobundles with Graphene as Promising Electrode Materials for Supercapacitors. Journal of Colloid and Interface Science 2015, 460, 303-309.

32. Wang, T.; Liu, Q.; Li, G.; Xu, K.; Zou, R.; Hu, J., Hydrothermal Control Growth of $\mathrm{Zn}_{2}$ $\mathrm{GeO}_{4}$-Diethylenetriamine 3d Dumbbell-Like Nanobundles. CrystEngComm 2014, 16, 32223227.

33. Abdelwahab, A.; Carrasco-Marín, F.; Pérez-Cadenas, A. F., Carbon Xerogels Hydrothermally Doped with Bimetal Oxides for Oxygen Reduction Reaction. Materials 2019, $12,2446$.

34. Mahala, C.; Basu, M., Nanosheets of $\mathrm{NiCo}_{2} \mathrm{O}_{4} / \mathrm{Nio}$ as Efficient and Stable Electrocatalyst for Oxygen Evolution Reaction. ACS Omega 2017, 2, 7559-7567.

35. Yang, Y.; Zeng, D.; Yang, S.; Gu, L.; Liu, B.; Hao, S., Nickel Cobaltite Nanosheets Coated on Metal-Organic Framework-Derived Mesoporous Carbon Nanofibers for HighPerformance Pseudocapacitors. Journal of colloid and interface science 2019, 534, 312-321. 
36. Liu, X.; Huang, Y.; Zhang, N.; Zhang, Z.; Yan, J.; Zong, M.; Liu, P., Fabrication of Carbon-Doped $\mathrm{ZnCo}_{2} \mathrm{O}_{4}$ Yolk-Shell Microspheres Compounded with Magnetic Graphene for Enhanced Electromagnetic Wave Absorption Performance. Ceramics International 2019.

37. Nefedov, V.; Firsov, M.; Shaplygin, I., Electronic Structures of Mrho2, Mrh2o4, Rhmo4 and Rh2mo6 on the Basis of X-Ray Spectroscopy and Esca Data. Journal of Electron Spectroscopy and Related Phenomena 1982, 26, 65-78.

38. Dong, X.-C.; Xu, H.; Wang, X.-W.; Huang, Y.-X.; Chan-Park, M. B.; Zhang, H.; Wang, L.-H.; Huang, W.; Chen, P., 3d Graphene-Cobalt Oxide Electrode for High-Performance Supercapacitor and Enzymeless Glucose Detection. ACS nano 2012, 6, 3206-3213.

39. Du, J.; Cheng, F.; Wang, S.; Zhang, T.; Chen, J., M(Salen)-Derived Nitrogen-Doped M/C $(\mathrm{M}=\mathrm{Fe}, \mathrm{Co}, \mathrm{Ni})$ Porous Nanocomposites for Electrocatalytic Oxygen Reduction. Scientific Reports 2014, 4, 4386.

40. Kong, A.; Kong, Y.; Zhu, X.; Han, Z.; Shan, Y., Ordered Mesoporous Fe (or Co)-NGraphitic Carbons as Excellent Non-Precious-Metal Electrocatalysts for Oxygen Reduction. Carbon 2014, 78, 49-59.

41. Masa, J.; Zhao, A.; Xia, W.; Muhler, M.; Schuhmann, W., Metal-Free Catalysts for Oxygen Reduction in Alkaline Electrolytes: Influence of the Presence of Co, Fe, Mn and Ni Inclusions. Electrochimica Acta 2014, 128, 271-278.

42. Daems, N.; Sheng, X.; Vankelecom, I. F.; Pescarmona, P. P., Metal-Free Doped Carbon Materials as Electrocatalysts for the Oxygen Reduction Reaction. Journal of Materials Chemistry A 2014, 2, 4085-4110. 
43. Biswas, S.; Drzal, L. T., Multilayered Nanoarchitecture of Graphene Nanosheets and Polypyrrole Nanowires for High Performance Supercapacitor Electrodes. Chemistry of Materials 2010, 22, 5667-5671.

44. Kabbabi, A.; Gloaguen, F.; Andolfatto, F.; Durand, R. J. J. o. E. C., Particle Size Effect for Oxygen Reduction and Methanol Oxidation on Pt/C inside a Proton Exchange Membrane. 1994, 373, 251-254.

45. Shao, M.; Peles, A.; Shoemaker, K., Electrocatalysis on Platinum Nanoparticles: Particle Size Effect on Oxygen Reduction Reaction Activity. Nano letters 2011, 11, 3714-3719.

46. Su, Y.; Zhu, Y.; Jiang, H.; Shen, J.; Yang, X.; Zou, W.; Chen, J.; Li, C., Cobalt Nanoparticles Embedded in N-Doped Carbon as an Efficient Bifunctional Electrocatalyst for Oxygen Reduction and Evolution Reactions. Nanoscale 2014, 6, 15080-15089. 